Proceedings of the 2018 International Scientific Conference 'Economic Sciences for Agribusiness and Rural Economy' No 2, Warsaw, 7-8 June 2018, pp. 252-256

\title{
DUTCH DISEASE IN OIL-EXPORTING COUNTRIES: A SURVEY OF THEORY AND EVIDENCE
}

\author{
Katarzyna Czech, $\mathrm{PhD}^{1}$ \\ Faculty of Economic Sciences, Warsaw University of Life Sciences - SGGW
}

\begin{abstract}
Dutch disease phenomenon can be observed in a country that discovers an important and substantial natural resource deposit and starts exporting it on a large scale. In consequence, the country's currency appreciates reducing competitiveness of its traditional export sector, including agricultural sector. The Dutch disease is considered to be one of the most significant reasons for the natural resource curse. The aim of the paper is to consolidate a growing literature on the Dutch disease and to provide theoretical framework for analysing this phenomenon. It refers to both developed and developing oil-exporting countries. The paper stresses the fact that the vulnerability to the Dutch disease depends strongly on economic policy, political regime and quality of institutions.
\end{abstract}

Keywords: Natural resource curse, Dutch disease, oil market JEL codes: F43, O13, Q32, Q33

\section{INTRODUCTION}

Oil is one of the most important commodities in the world. There are countries that highly depend on oil income. Surprisingly, market evidence suggests that natural resources, including oil, may be a curse rather than blessing, since many resource-rich countries tend to develop slower than resource-poor ones. The phenomenon gives a rise to a concept known as the natural resource curse (Gelb, 1988; Auty, 1993). Sachs and Warner are among the first researchers who empirically test the relationship between natural resource abundance and country's economic growth. They find evidence that resource-poor countries perform generally better than resource-rich countries (Sachs and Warner, 1999, 2001). However, it concerns mainly the countries that overwhelmingly rely on income derived from natural resources. Gylfason includes in his research another economic indicators that are likely to be negatively affected by a discovery of an important and substantial natural resource deposit. He shows that natural resources may bring adverse effects on country's human capital, economic policies, level of savings and investments, and institutions (Gylfason, 2001, 2006; Gylfason and Zoega, 2006).

There are two main streams in literature that explain the natural resource curse (Badeeb, Lean and Clark, 2017). The first one is focused on economic and the second one on political explanations. The Dutch disease, long-term trends in world prices, commodity prices' volatility, permanent crowding out of manufacturing, the neglect of education and failures of economic policy are among the most important

${ }^{1}$ Corresponding author: Nowoursynowska 166, 02-787 Warsaw, Poland, katarzyna_czech@sggw.pl, +4822 5934112 
economic reasons of resource curse (Van der Ploeg and Poelhekke, 2009; Frankel, 2010). Political explanations, on the other hand, embrace rent seeking, weak institutions and corruption (Iimi, 2007; Eregha and Mesagan, 2016).

The Dutch disease is considered to be one of the most significant triggers for the natural resource curse. The paper is focused on the Dutch disease phenomenon among oil-exporting countries. It should be emphasized that there are different approaches to the problem of Dutch disease among oil-exporting countries. There exists a striking contrast especially in their fiscal and monetary policy adjustments to the oil boom. The aim of the paper is to consolidate a growing literature on the Dutch Disease and to provide theoretical framework for analysing this phenomenon. It refers to both developed and developing oil-exporting countries. The paper is organised as follows. Section 2 contains literature review concerning the Dutch disease concept. Section 3 surveys empirical studies testing for Dutch disease effect in both developed and developing oil-exporting countries. Section 4 summarizes and concludes.

\section{DUTCH DISEASE. A SURVEY OF THEORY}

Adam Smith and David Ricardo, two main classical economists, claim that countries with abundant natural resources perform economically better than those without. This belief was supported by many post-war economists, especially in the early 1970 s. The situation has changed in the late 1970 s, when the so called Dutch disease occurred. The term was introduced by 'The Economist' in 1977 and reflected the crisis in the Netherlands driven by discoveries of vast gas deposits in the North Sea, in 1959 (Badeeb, Lean and Clark, 2017). The appreciation of the Dutch guilder, followed by the gas export boom, led to deindustrialization, decline in traditional export of tradable sectors and price increase in non-traded goods and services ${ }^{2}$.
In economic literature, the Dutch disease model was introduced by Corden and Neary (1982). The Dutch disease is a phenomenon related to adverse effects that result from discovering new natural resources. The production and export of natural resources lead to country's currency overvaluation, and in consequence, generate adverse externalities in other sectors of tradable goods and services. It altogether hampers those sectors from developing, regardless of the level of applied technology, their innovation regime, quality of labour force etc.

The Dutch disease model assumes that the economy comprises three sectors: a tradable sector of natural recourses, a tradable manufacturing sector and a non-traded sector. Moreover, a tradable sector of natural recourses and a tradable manufacturing sector are presumed to be booming and lagging sub-sectors, respectively. The Dutch disease occurs when the boom in natural recourse market (e.g. oil) leads to a rise of domestic income, money supply and demand for goods. This, in turn, brings about high inflation and appreciation of real currency. In a process, higher domestic prices and stronger home currency make the country's export of other goods in a tradable manufacturing and agricultural sector less competitive. This adverse effect is called 'the spending effect' (Corden and Neary, 1982). There is also another negative consequence (so-called 'pull effect') that squeezes the non-resource manufacturing and agricultural sector (Badeeb, Lean and Clark, 2017). The 'pull effect' is associated with the situation when, in a result of boom in natural recourses, domestic input prices increase and generate a rise in the production cost of other tradable sectors such as manufacturing and agriculture. It altogether hampers the overall growth of non-resource tradable sector.

However, it should be added that the Dutch disease is likely to lead to the expand of non-traded sector. Higher domestic income and higher personal revenues conduce to the increase of demand for non-

\footnotetext{
${ }^{2}$ Domestic production structure embraces the traded and non-traded goods sectors. Tradable goods include those production activities that are traded internationally (e.g. shoes, cars, food, copper, etc.) and their price is determined in the world market. Non-tradable sector involve items which consumers and producers are in the same location and a price is determined by supply and demand in the local market. Non-tradable goods and services include electricity, water supply, public services, real estate, construction, local transportation etc.
} 
traded goods and the rise in their prices. It is favourable to the growth of that sector mostly during the time of boom in the natural resource market, when the money supply increases.

\section{OIL-DEPENDENT ECONOMIES}

Natural resource dependence is defined as a degree to which a country economic performance is determined by resource revenues. Natural resource dependence is very often measured by the ratio of natural resource rents relative to gross domestic product (GDP) or as a percentage of natural resource export to total country's export (Auty 2007; Dietz, Neumayer and De Soysa 2007).

Figure 1 presents the countries that are most dependent on oil revenues. Data reflects oil rents as a share of GDP in 2016. Oil rents are estimated as a difference between the value of crude oil production at world prices and total cost of production.

Among the 21 countries that highly rely on oil rents, oil dependence ranges from 3.8\% in Norway, to $44 \%$ and $42.4 \%$ in Kuwait and Iraq, respectively. Apart from Kuwait and Iraq, Saudi Arabia, Oman, Congo Republic, Azerbaijan and Qatar represent those countries where oil rents are more than $15 \%$ share of GDP.

Sachs and Warner (1995), Gylfason et al. (1999), Leite and Weidmann (1999), Auty (2001), Manzano and Rigobon (2001), among others, demonstrate that the share of resource rents in GDP is negatively correlated with the GDP per capita growth rate and confirm that a high resource dependence can lead to negative development of resource-rich country. Auty (2001) shows that GDP per capita of resourcepoor countries has a tendency to grow much faster, even two to three times, than per capita incomes of resource abundant countries. Nili and Rastad (2007) find that oil-dependent countries' average per capita income has fallen $29 \%$ over the period 1975-2000. It is worth emphasizing that this indicator has increased by $34 \%$ for all countries of the world over the same period of time.

Mehrara (2008) finds that positive oil revenues shocks have a short-term positive and significant impact on economic growth. Negative oil shocks effects, on the other hand, have negative and significant impact. However, Mehrara (2008) shows that the effects of negative oil revenues shocks are over twice as large as effects from positive shocks. He points

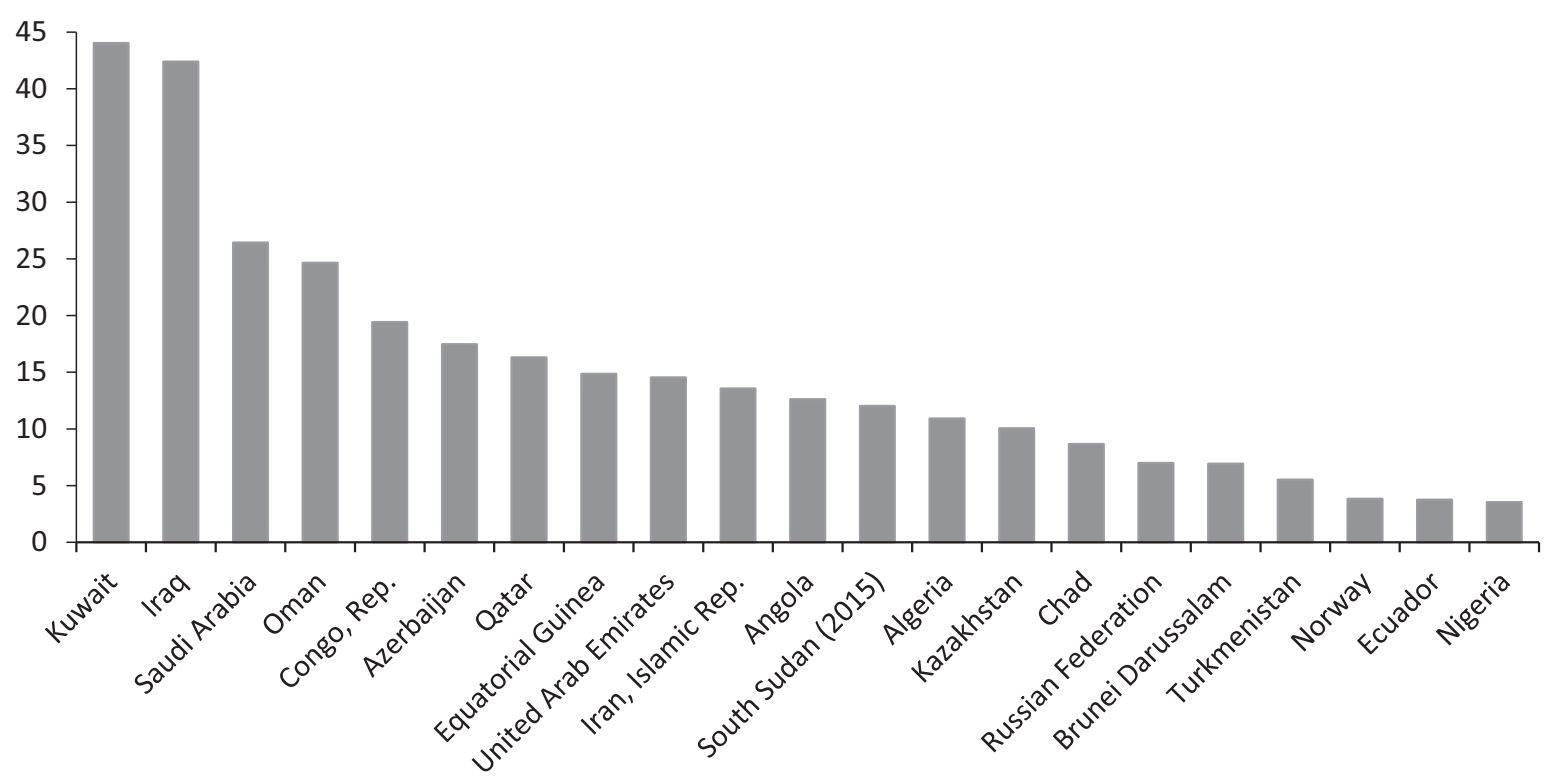

Figure 1. Oil rents as a share of GDP in 2016 (\%)

Source: own elaboration based on World Bank database. 
out that bust in the oil market seriously hampers economic growth, while oil boom has positive, but often contemporaneous and inconsiderable impact on economic growth. Therefore, the overall influence of oil revenues shocks on country's economic growth is very often negative and is taken as a symptom of the Dutch disease.

Nigeria is the example of developing country that has been suffering the Dutch disease from the late 1950 s, when its first oil deposits were discovered. Between 1965 and 2000 oil revenues per capita increased there from USD 33 to USD 325, while per capita income almost did not change. The part of population that has to survive on less than 1 USD per day climbed from $26 \%$ in 1970 to almost $70 \%$ in 2000 (Van der Ploeg, 2011). Apart from Nigeria, there are many other developing countries that are highly vulnerable to the Dutch disease like for example Algeria, Congo, Mexico, Saudi Arabia, Venezuela, Zambia (Tornel and Lane, 1999; Torvik, 2002). Botswana, Chile, Malaysia, Oman, Thailand are, on the other hand, among developing countries that have been able to avoid the Dutch disease. Most of the developed oil-dependent countries seem to be more resistant to the Dutch disease. Mehlum, Moene and Torvik(2006) confirm it for Australia, Canada, Norway, United States, the countries which are both rich in natural resources and have high per capita income. They claim that quality of institution determines the country's vulnerability to the Dutch disease phenomenon.

It should be stressed that there is a substantial difference in a policy adjustment to the oil boom between resource-rich countries. They have distinct views on both fiscal and monetary policy, and different type of political regime. There is a huge body of literature that shows that country's economic policy, political regime and quality of institutions determine whether countries are able to avoid the Dutch disease and the natural resource curse (Van der Ploeg, 2011).

\section{CONCLUSIONS}

Natural resource boom has positive impact on resource-rich country, however, an increase in foreign exchange inflows may have also a negative long-term effects known as the natural resource curse. One of the most significant triggers for the natural resource curse is called the Dutch disease. Dutch disease phenomenon may touch a country that discovers an important and substantial natural resource deposit and starts exporting it on a large scale. In consequence, the country's currency appreciates reducing export's competitiveness of other goods, including agricultural items, and conducing to a decrease in their production. Furthermore, the Dutch disease is likely to lead to the expand of a non-traded sector and increase in price of non-traded goods. It altogether may be harmful for oil-rich countries' economy, especially during a time of negative oil price shocks. Many researchers study the relationship between oil dependence and economic growth of rich-oil countries. The vast majority of them confirm the negative link between these variables. However, it needs to be emphasized, that their results are highly influenced by the choice of analysed country. The vulnerability to the Dutch disease depends strongly on economic policy, political regime and quality of institutions.

Economists struggle to find the solution to negative externalities associated with the Dutch disease phenomenon. It is worth emphasizing that during the boom in the natural resources market high profits are incorporated in the country's government budget. Real appreciation of the currency may be avoided by accumulating budget surpluses. However, revenue sterilization and accumulation requires a mature, long-distance results-oriented government, which is able to resist the pressure of enjoying high oil profits in short-run period. It should be stressed that a shorthorizon of the government's power gives an edge to that problem. There is a huge temptation for governments to achieve short-term political goals by using windfall oil revenues (Roemer, 1983). Atkinson and Hamilton (2003) find that resource-rich countries with effective, high-quality institutions are more likely to mitigate the negative consequences of natural resource curse phenomenon. Van der Ploeg (2011) stresses that the resource curse is not etched in stone. This belief may be pictures by the phrase below (Van der Ploeg, 2011): 'Resource rich countries with good institutions, trade openness, and high investments in exploration technology seem to enjoy the fruits of their natural resource wealth.' 


\section{REFERENCES}

1. Atkinson, G., Hamilton, K. (2003). Savings, growth and the resource curse hypothesis. World Development, 31 (11), pp. 1793-1807.

2. Auty, R. (1993). Sustaining development in mineral economies: the resource curse thesis. Routledge, London.

3. Auty, R.M. (ed.). (2001). Resource abundance and economic development. Oxford University Press, Oxford

4. Auty, R.M. (2007). Natural resources, capital accumulation and the resource curse. Ecological Economics, 61 (4), pp. 627-634.

5. Badeeb, R.A., Lean, H.H., Clark, J. (2017). The evolution of the natural resource curse thesis: A critical literature survey. Resources Policy, 51, pp. 123-134.

6. Corden, W.M., Neary, J.P. (1982). Booming sector and de-industrialisation in a small open economy. The Economic Journal, 92 (368), pp. 825-848.

7. Dietz, S., Neumayer, E., De Soysa, I. (2007). Corruption, the resource curse and genuine saving. Environment and Development Economics, 12 (1), pp. 33-53.

8. Eregha, P.B., Mesagan, E.P. (2016). Oil resource abundance, institutions and growth: Evidence from oil producing African countries. Journal of Policy Modeling, 38 (3), pp. 603-619.

9. Frankel, J.A. (2010). The natural resource curse: a survey. HKS Faculty Research Working Paper Series. RWP10-005. John F. Kennedy School of Government, Harvard University, Cambridge MA.

10. Gelb, A.H. (1988). Oil windfalls: Blessing or curse? Oxford University Press, Washington.

11. Gylfason, T. (2001). Natural resources, education, and economic development. European Economic Review, 45 (4-6), pp. 847-859.

12. Gylfason, T. (2006). Natural resources and economic growth: From dependence to diversification. In: Economic liberalization and integration policy. Springer, Berlin, Heidelberg, pp. 201-231.

13. Gylfason, T., Herbertsson, T.T., Zoega, G. (1999). A mixed blessing: natural resources and economic growth. Macroeconomic Dynamics, 3 (2), pp. 204-225.

14. Gylfason, T., Zoega, G. (2006). Natural resources and economic growth: The role of investment. The World Economy, 29 (8), pp. 1091-1115.
15. Leite, M.C., Weidmann, J. (1999). Does mother nature corrupt: Natural resources, corruption, and economic growth. International Monetary Fund, Washington.

16. Iimi, A. (2007). Escaping from the Resource Curse: Evidence from Botswana and the Rest of the World. IMF Staff Papers, 54 (4), pp. 663-699.

17. Manzano, O., Rigobon, R. (2001). Resource curse or debt overhang? National Bureau of Economic Research Working Paper 8390. DOI: 10.3386/w8390

18. Matsen, E., Torvik, R. (2005). Optimal Dutch Disease. Journal of Development Economics, 78 (2), pp. 494-515 .

19. Mehlum, H., Moene, K., Torvik, R. (2006). Institutions and the resource curse. The Economic Journal, 116 (508), pp. 1-20.

20. Mehrara, M. (2008). The asymmetric relationship between oil revenues and economic activities: The case of oil-exporting countries. Energy Policy, 36 (3), pp. 1164-1168.

21. Nili, M., Rastad, M. (2007). Addressing the growth failure of the oil economies: The role of financial development. The Quarterly Review of Economics and Finance, 46 (5), pp. 726-740.

22. Roemer, M. (1983). Dutch Disease in developing countries: swallowing bitter medicine. In: The Primary Sector in Economic Development: Proceedings of the Seventh Arne Ryde Symposium, Frostavallen, 29-30.08.1983. Routledge, London.

23. Sachs, J.D., Warner, A.M. (1995). Natural resource abundance and economic growth. National Bureau of Economic Research Working Paper 5398. DOI: $10.3386 / \mathrm{w} 5398$

24. Sachs, J.D., Warner, A.M. (1999). The big push, natural resource booms and growth. Journal of Development Economics, 59 (1), pp. 43-76.

25. Sachs, J.D., Warner, A.M. (2001). The curse of natural resources. European Economic Review, 45 (4-6), pp. 827-838.

26. Torvik, R. (2002). Natural resources, rent seeking and welfare. Journal of Development Economics, 67 (2), pp. 455-470.

27. Van der Ploeg, F. (2011). Natural resources: curse or blessing? Journal of Economic Literature, 49 (2), pp. 366-420.

28. Van der Ploeg, F., Poelhekke, S. (2009). Volatility and the natural resource curse. Oxford Economic Papers, 61 (4), pp. 727-760. 